Cumhuriyet International Journal of Education-CIJE

e-ISSN: 2147-1606

Vol 5 (3), 2016, 78 - 92

\title{
High School Students' Perception of University and Faculty Members
}

\author{
Zehra Sümeyye ERTEMำ, Asım ARI²
}

\section{Summary}

\section{PURPOSE}

Information society paradigm, globalization, lifelong learning, innovations in information and communication technology are some of the concepts that make change in the meaning of university. This change and regulations related with university are discussed by various circles and also in our country. As a concept how university can be described and how different segments of society perceive the concepts of higher education and university as well as faculty member concept, which can't be thought apart from "university", are among the topics that should be discussed. The purpose of this study is to investigate high school students' metaphoric perceptions of university and faculty members.

\section{METHOD}

In this study qualitative method was used and data were analyzed using content analysis method. This qualitative study aims to find out high school students' perception of university and faculty members. The participants were 404 students who were chosen according to maximum variation sampling. The data were collected through Metaphorical Perception of Universities and Faculty Members Survey then analyzed carefully by using qualitative content analysis method. At the first stage of analysis, the information on the form was transferred to a new Excel file. Then, all the metaphors supplied by the participants were coded and analyzed to characterize their topic, the vehicle and the ground. In the next stage, metaphors organized alphabetically were examined and abstracted the conceptual themes. In order to assure reliability, inter-coder reliability analysis was employed. In the last stage frequencies of the metaphorical images in each conceptual category were calculated.

\section{RESULTS AND DISCUSSION}

High school students have positive perception of university concept and negative perception of faculty members concept. Students used life and freedom for the university; dictator and boss for the faculty staff. This result reveals the importance of freedom and responsibility for being formed of students perceptions of university and faculty members concepts. The results of other studies indicate that for students the "school" is a place like "a prison" which shows that the students have highly negative perception about school. On the other hand in this study it is suggested that the students have positive perception about university. Although the schools have a negative impact on the students, the universities are a hope about future and life for them. They make much sense about university. The results also shows that students have negative perceptions about "faculty member" concept. For them, a faculty member is someone who is an expert in a field, who behaves like a "dictator" to the students and who gives orders to his or her students. Secondary education institutions, guidance and counseling service being in these institutions and teachers have responsibility in order to minimize the negative perception. In this study high school students' perceptions about university and faculty members. It should be researched the perceptions of other segments of society in future studies.

\footnotetext{
${ }^{1}$ Dr., Ministry of National Education, zsgokler@gmail.com

2 Assoc. Prof. Dr., Eskisehir Osmangazi University, Faculty of Education, ari@ogu.edu.tr
} 